\title{
Implementation of PWM AC chopper controller for capacitor run induction motor drive via bacterial foraging optimization algorithm
}

\author{
S. Gobimohan, N. Murali \\ Department of Electrical Engineering, Nizwa College of Technology, Oman
}

\section{Article Info}

Article history:

Received Feb 11, 2020

Revised Mar 19, 2020

Accepted May 27, 2020

\section{Keywords:}

Bacteria foraging optimization Field programmable gate array Functional point PID control Settling time

\begin{abstract}
This paper focuses on design of closed-loop control for pulse width modulated AC chopper controlled capacitor run induction motor drive engaging enriched optimization algorithm based on foraging of bacteria. Capacitor run induction motor is a non-linear device and its parameter varies under different functional point of the system. A linearized increment model for PWM AC chopper is illustrated for a particular functional point of the drive. The conventional method does not provide acceptable performance under different load conditions. Bacteria foraging optimization technique categorizes accurate control parameters for the superlative dynamic response under unit step load variations. Field Programmable Gate Array is implemented practically for a particular functional point of the drive to exhibit accurate performance. Experimental and simulated results are obtained to authenticate the effectiveness of the optimized controller.
\end{abstract}

This is an open access article under the CC BY-SA license.

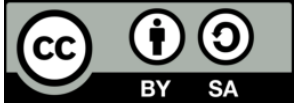

\section{Corresponding Author:}

S. Gobimohan,

Department of Electrical Engineering,

Nizwa College of Technology,

Nizwa-Izki Road, PO Box 477 Nizwa, 611 Ad Dakhiliyah Oman.

Email: gobi.sivasubramanian@nct.edu.com

\section{INTRODUCTION}

The capacitor run single phase induction motor is widely used in all applications due to less cost, being robust and easier maintenance. The closed-loop control of capacitor run induction motor drive gives good performance under any load conditions. It employs pulse width modulation AC chopper which is widely used in domestic and industrial applications. The closed-loop control is emulated by using artificial neural network for three phase induction motor [1]. The feedback controller is highly effective using ant colony optimization and genetic algorithm for three phase induction motor and formulated the hypothesis for closed-loop control mechanisms [2,3]. For capacitor run induction motor the closed-loop control is available in simulation only but in hardware only pragmatic approach is followed. The application of PWM AC chopper utilizes different loads like centrifugal fan and water pumping [4, 5]. The simulation based closedloop control is realized using fuzzy logic controller [6-8] and the diverse operating point is not considered is a major demerit.

The controller for single phase induction motor is implemented using microcontroller to check the reference and set speed. In this paper the performance parameters like settling time and peak overshoot is not considered [9, 10]. The optimal controller design is depicted using particle swarm optimization for control induction motor. The drawback is design of PID controller is done by simulation only [11]. 
The performance of capacitor run induction motor was exhibited with high torque, efficiency and suitable simple AC voltage controller utilized in [12-16].

The modeling of single phase induction motor is estimated by the direct and quadrature axis an equation resulting in fifth order matrix with decoupled equations is depicted in [17, 18]. In this paper the controller design is attained by bacteria foraging optimization algorithm $[19,20]$ along with different topologies and other applications of filter design is achieved by optimization techniques [21, 22]. The closedloop control is demonstrated using pulse width modulated AC chopper fed capacitor run induction motor. The logic in algorithm is based on E. coli a bacterium which carries information of the problem and corresponding solution is obtained when all the bacteria are aligned towards the normal environment. The association of bacteria towards one region is topographically compared to real time situations.

The closed-loop control gains of PWM chopper fed capacitor run induction motor drive is envisioned for best performance. The dq modeling of induction motor is a fifth order transfer function and it is abridged to first order by Taylor series method. The dynamic response is undertaken when variation of strictures under different loading cnditions for a particular reference speed. The non-linear induction motor has different functional points and it varies largely under different loading conditions. The optimal control is designed by bacterial foraging method to achieve best dynamic response for different functional points.

\section{MODELLING OF CAPACITOR RUN INDUCTION MOTOR} as in [23].

The electromagnetic torque developed by variable voltage controller for induction motor written

$$
T_{e m}=f(V, \omega)
$$

Where $T_{e m}$ is the electromagnetic torque, $\mathrm{V}$ is the motor phase voltage and $\omega$ is motor speed in radians per second. The voltage is varied for different duty cycles by pulse width modulation AC chopper. Hence the electromagnetic torque equation can be written as

$$
T_{e m}=f(D, \omega)
$$

where D is the duty cycle of the PWM AC chopper. Assuming small perturbations on each variable from (2). The induction motor drive is a fifth order transfer function and it is reduced to linear first order model by Taylor series. The linear first order equation is given in (3). Henceforth the momentary process is pronounced by the equation given below [24].

$$
\Delta T_{e m}=K_{D} * \Delta D+K_{W} * \Delta \omega
$$

Where

$$
\begin{gathered}
K_{D}=\frac{\Delta T_{e m}}{\Delta D} \text { at } \omega=\text { constant } \\
K_{W}=\frac{\Delta T_{e m}}{\Delta \omega} \text { at Duty ratio }=\text { constant }
\end{gathered}
$$

From the basics of machines theory, the load torque equation can be illustrated by the combination of moment of inertia, viscous friction and the motor torque. The equation is given below

$$
J \frac{d \Delta \omega}{d t}+B \Delta \omega=\Delta T_{e m}-\Delta T_{L}
$$

where $\mathrm{J}$ is the moment of inertia, $\mathrm{B}$ is the viscous friction and $\mathrm{T}_{\mathrm{L}}$ is the load torque.

The PWM AC chopper fed capacitor run induction motor is operated under steady state condition. The corresponding speed torque characteristics are obtained for various duty cycles of chopper. In order to determine the constants $\mathrm{KD}$ and $\mathrm{K}_{\mathrm{W}}$, a particular functional point under consideration is selected for the duty 
ratio of 0.8 and angular speed of 150 radians per second. The disturbance load torque is selected as $1 \mathrm{Nm}$ at 0.5 seconds. The steady state speed torque characteristic is drawn for one functional point and is shown in Figure 1. The different values of $\mathrm{K}_{\mathrm{D}}$ and $\mathrm{KW}$ are listed in Table 1 for different functional points. The inference from the table is the functional point varies for different instances. The value of $K_{D}$ varies at larger value while the values of $\mathrm{K}_{\mathrm{W}}$ variations are of lesser value. The closed-loop controller of small signal model of capacitor run induction motor is shown in Figure 2. The particular functional point and the corresponding constants $\mathrm{K}_{\mathrm{D}}$ and $\mathrm{K}_{\mathrm{W}}$ are implemented using PID controller.

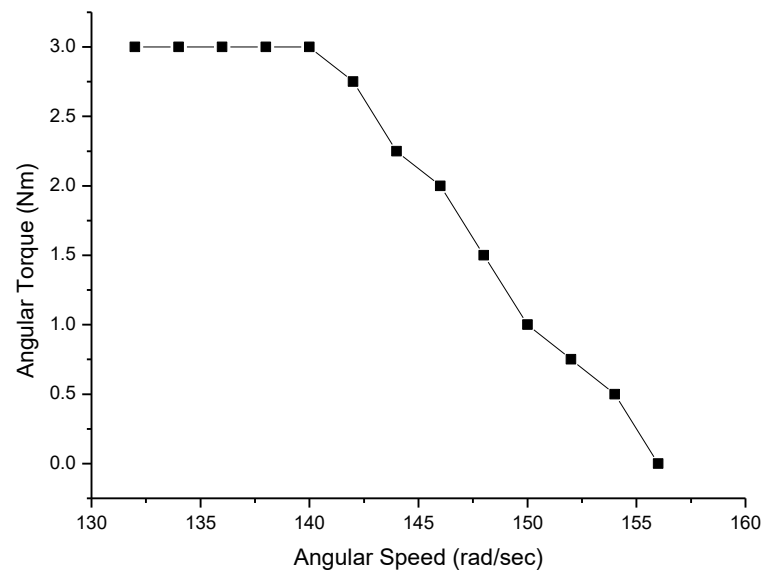

Figure 1. Determination of $\mathrm{K}_{\mathrm{D}}$ and $\mathrm{K}_{\mathrm{W}}$ by steady state characteristics of PWM chopper fed induction motor drive

Table 1. Different functional point

\begin{tabular}{ccccc}
\hline S. No & Duty ratio & $\omega$ & $\mathrm{K}_{\mathrm{D}}$ & $\mathrm{K}_{\mathrm{w}}$ \\
\hline 1 & 0.70 & 144.8 & 10.75 & -0.206 \\
2 & 0.74 & 146.4 & 11.5 & -0.191 \\
3 & 0.78 & 148.6 & 19.25 & -0.239 \\
\hline
\end{tabular}

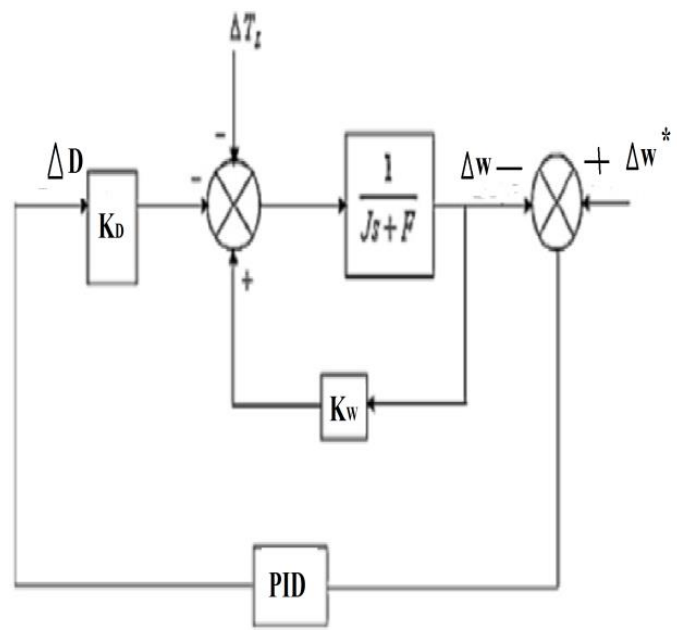

Figure 2. PID controller of capacitor induction motor

The reference speed $\Delta \omega *$ in the block diagram is presumed to be zero as shown in Figure 2. From the block diagram, transfer function is derived along with the disturbance load torque of $1 \mathrm{Nm}$ is shown in (7).

$$
\frac{\Delta \omega}{\Delta T_{L}}=\frac{-S}{S^{2}\left(K_{D} * K_{d}+J\right)+S\left(B+K_{D} * K_{p}-K_{W}\right)+K_{D} * K_{i}}
$$


where $\mathrm{Kp}$ is proportional gain, $\mathrm{Ki}$ is integral gain, and $\mathrm{Kd}$ is the derivative gain. The induction motor drive response is done simulation for a unit step input at $\mathrm{t}=0$. The load torque disturbance of $1 \mathrm{Nm}$ is applied at $\mathrm{t}$ $=0.5$ seconds. The simulation of drive is done for a particular functional point and the corresponding values of $\mathrm{K}_{\mathrm{D}}$ and $\mathrm{K}_{\mathrm{W}}$ are taken into consideration. The transient response is shown in Figure 3 for the different functional points of the capacitor run induction motor. It is noted that the functional point will be satisfied only for the corresponding values $\mathrm{K}_{\mathrm{D}}$ and $\mathrm{K}_{\mathrm{W}}$. For other functional points it does not assure realistic response.

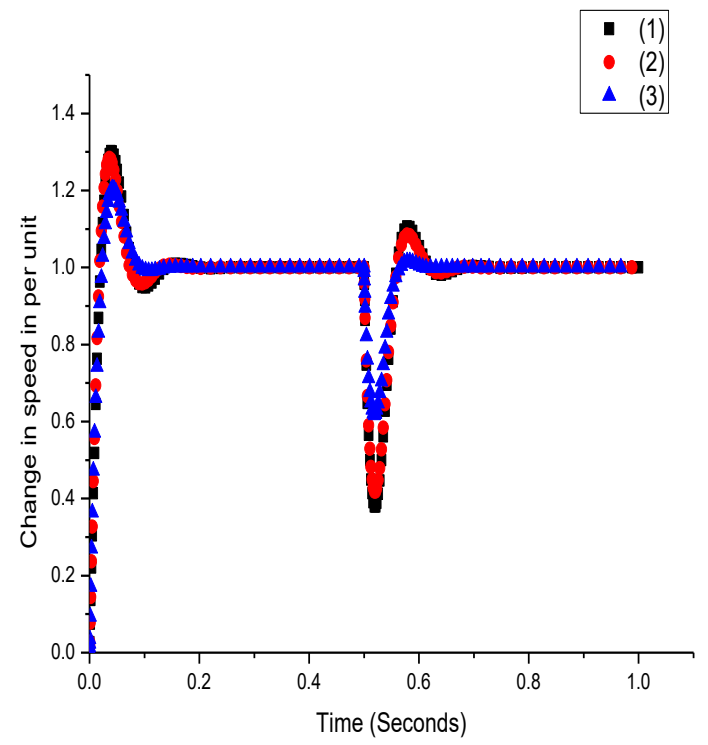

Figure 3. Different functional point of speed response with PID controller

\section{DESIGN OF CONTROLLER USING BACTERIAL FORAGING OPTIMIZATION}

Bacteria foraging optimization proposed first by Passino [25] and is based on real time E. coli present in the intestines of human body. The basic operation of E. coli bacteria is when the nutrients available it forages in small steps and grows, while in noxious environment bacteria dies and moves away. The real bacteria forage shortest path and find the new position with high fitness value. This phenomenon leads to global optimum solution. The movement of each bacterium depends upon the coordinate of the search space. Initially the coordinate of bacterium is chosen randomly, when the nutrients available in the bacterium forage to a new position and the objective function is minimized. This ultimate effect causes the set of bacteria to locate the best position and optimum solution is achieved. Under bad environment the bacteria moves away and optimum position is not reached. In this paper the performance of capacitor run induction motor drive is enumerated by the design of controller gains utilizing optimization techniques. The objective function is chosen depending on the performance parameters of the response. The performance parameters are the settling time and peak overshoot specified by ts and Mp respectively. The objective function is written as

$$
F(\varphi)=(1+M p) *(1+t s)
$$

Subject to $\varphi_{\min } \leq \varphi \leq \varphi_{\max }$

where $\varphi$ is the set that contains controller gains of $\mathrm{Kp}, \mathrm{Ki}$ and $\mathrm{Kd}$.

The bacterial foraging optimization technique is described below. It has four process, chemotactic, reproduction, elimination and dispersal. Initialize the parameters of the bacteria foraging optimization algorithm they are dimension of search space, number of bacteria, number of chemotactic step, limits of length of swim, number of reproductive steps, number of elimination and dispersal steps, the number of bacteria reproduction split, probability of elimination, run length and initial positions. The term $\mathrm{Q}(\mathrm{i}, \mathrm{j}, \mathrm{k}, \mathrm{l})$ term represents the total core of the algorithm where $\mathrm{i}$ embodies the number of bacteria, $\mathrm{j}$ embodies the chemotactic loop, $\mathrm{k}$ embodies the reproduction loop and finally 1 embodies the elimination and dispersal event. The parameters which are required for searching the optimum gains are proportional, integral and derivative gains. 
In the chemotactic step depending on the nutrients the flagella will move towards the positive gradient. The flagella will move either in clockwise direction as swimming and counter-clockwise direction as tumbling operations. The process of reproduction operator is that healthier bacteria survive and least healthy bacteria will split into two and maintains the total bacteria in the process in operation. The next event is elimination and dispersal operation in which most of the bacteria does not survive due changes in the environment. The healthier bacteria will evolve and move towards the positive gradient. The remaining bacterium does not survive or it will diminish due to environment conditions [26].

$$
Q(i, j+1, k, l)=Q(i, j, k, l)+L(i) \frac{\Delta(i)}{\sqrt{\Delta^{T}(i) \Delta(i)}}
$$

Now calculate the fitness function $\mathrm{F}(\mathrm{i}, \mathrm{j}, \mathrm{k}, \mathrm{l})$. for swim operation initialize swim length and if swim length is less than the limits of swim length. When bacterium swimming better then let swim length $=$ swim length +1 , if $F(i, j, k, l)<$ Flast then Flast $=F(i, j, k, l)$, so that movement of bacteria in same direction given by (8). Else, let swim length = limits of swim length, go to the next bacterium and compute the fitness function.

Step 4: if $\mathrm{j}$ < number of chemotactic step, then go to step 3 as chemotaxis step is not complete

Step 5: in reproduction with the present values of $k, 1$ for each value of $i=1,2 \ldots$ number of bacteria, calculate global fitness function. In this higher cost function bacteria will die and lower cost function will grow and it split in to two asexually. This keeps the search space constant.

Step 6: if $\mathrm{k}<$ number of reproductive steps, go to step 2 and restart the chemotaxis process

Step 7: elimination and dispersal process, by eliminating the bacterium and disperse the remaining bacteria in a random location. When $1<$ number of elimination and dispersal go to step 2 or when the objective function converges it comes an end. The optimum controller gains are obtained by this method.

\section{RESULTS AND ANALYSIS}

The bacteria foraging optimization algorithm was simulated using MATLAB software. The parameters taken are enumerated below.

Dimension of search space: 6

Number of bacteria: 20

Number of chemotactic steps: 10

Limits of length of swim:4

Number of reproductive steps: 4

Number of elimination and dispersal steps: 2

Probability of elimination: 0.75

The results are obtained by using optimization algorithm and the convergence of the objective function is shown in Figure 4. The optimum values of different controller gains are obtained by the simulation. The inference is that initially bacterium is at random locations and all the bacteria converge to a specified location to get global optimum solution. The optimum values of controller gains are $\mathrm{Kp}=1.05, \mathrm{Ki}$ $=90$ and $\mathrm{Kd}=0.00013$ respectively. The response of motor is illustrated by step input at two different time intervals. The time intervals are applied at $\mathrm{t}=0$ and $\mathrm{t}=0.5$ seconds. At time $\mathrm{t}=0$ seconds for a step input of per unit speed of 1 is applied and at $\mathrm{t}=0.5$ seconds for a step input of $1 \mathrm{~N}-\mathrm{m}$ is applied as the disturbance torque.

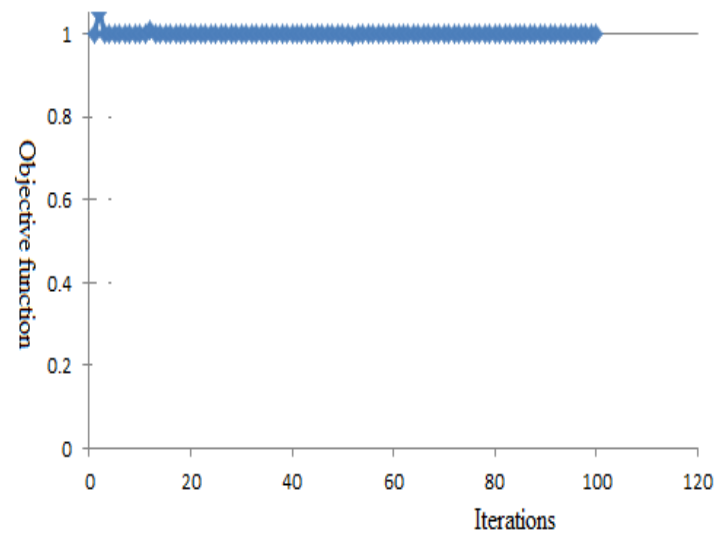

Figure 4. Objective function variation of best bacteria 
The waveform is obtained for conventional controllers are shown in Figure 5 and Figure 6. The waveform of bacteria foraging optimization controller is shown in Figure 7 and Figure 8. It is inferred that conventional controller shows very large change in output after disturbance and their settling time is more after applying load. The bacteria foraging optimization depicts superlative performance under sudden change in load.

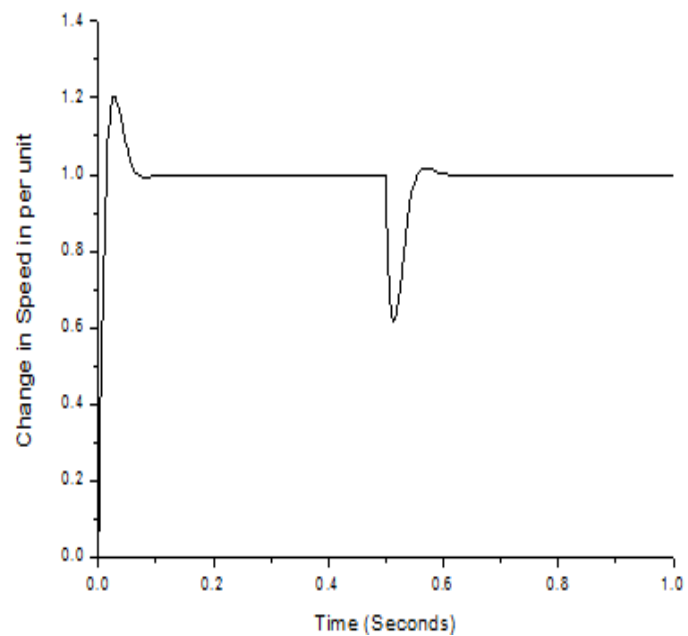

Figure 5. Conventional speed response by simulation

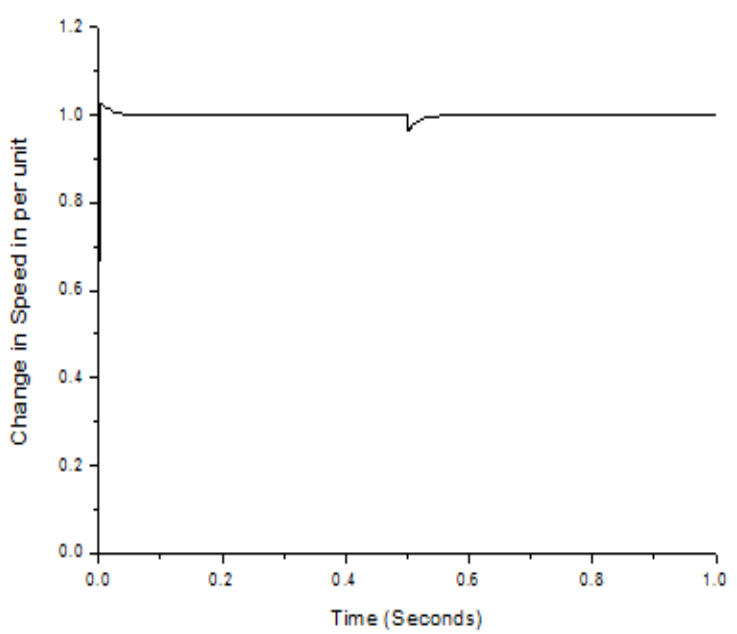

Figure 7. BFO speed response by simulation

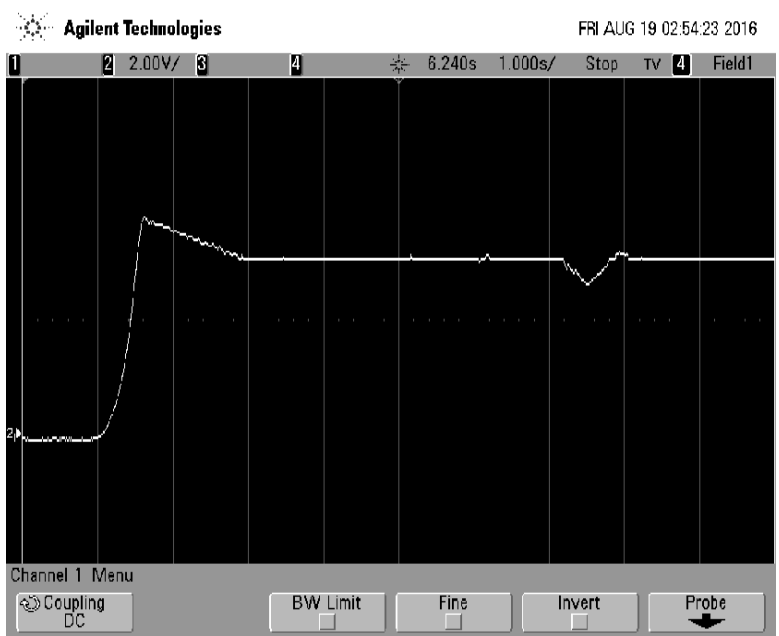

Figure 6. Conventional speed response by hardware

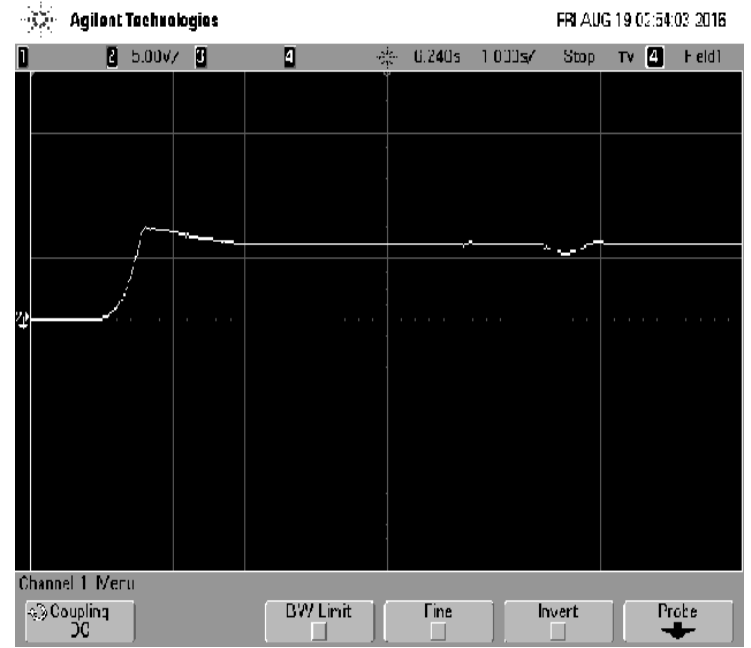

Figure 8 . BFO speed response by hardware

The FPGA uses Xilinx software and the program is written in VHDL. The VHDL programming is a powerful tool in embedded systems and the concept of power electronics application in electrical machines is well suited for different outcomes. The main advantage of FPGA to other controllers is coding can be easily embedded in the chip and any modification can be updated by the program. The hardware is done by using the closed-loop control of capacitor run induction motor. The program is shown in Figure 9. The response of PID controlled capacitor run induction motor dynamic response is emulated using matlab software and field programmable gate array based triggering scheme. The judgment clearly shows that there is good arrangement between simulation and experimental results which is depicted and shown above. The experimental setup is shown in Figure 10 in which the capacitor run induction motor is coupled with mechanical load. The Figure 10 depicts the experimental setup for capacitor run induction motor for performing closed loop control. 


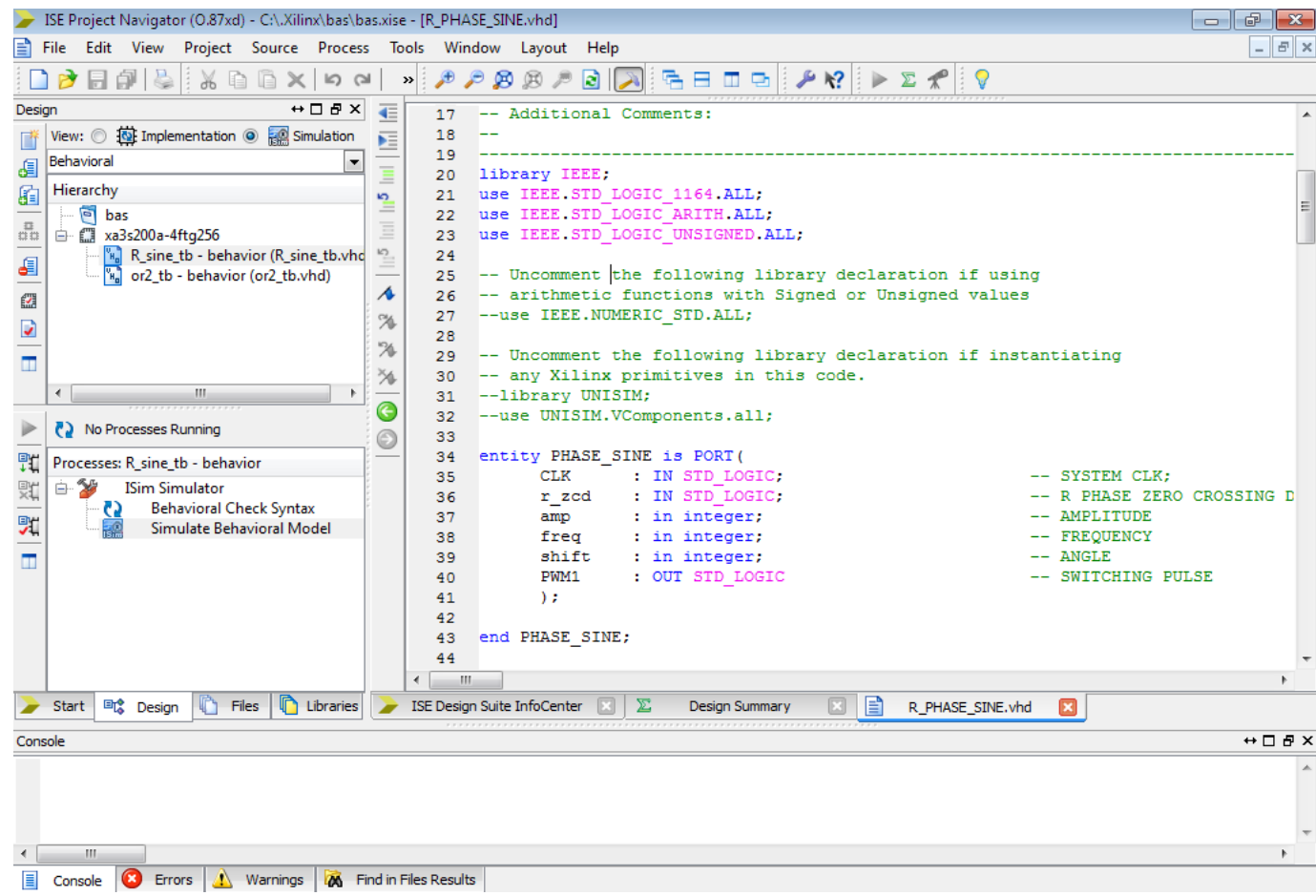

Figure 9. FPGA programming using Xilinx software

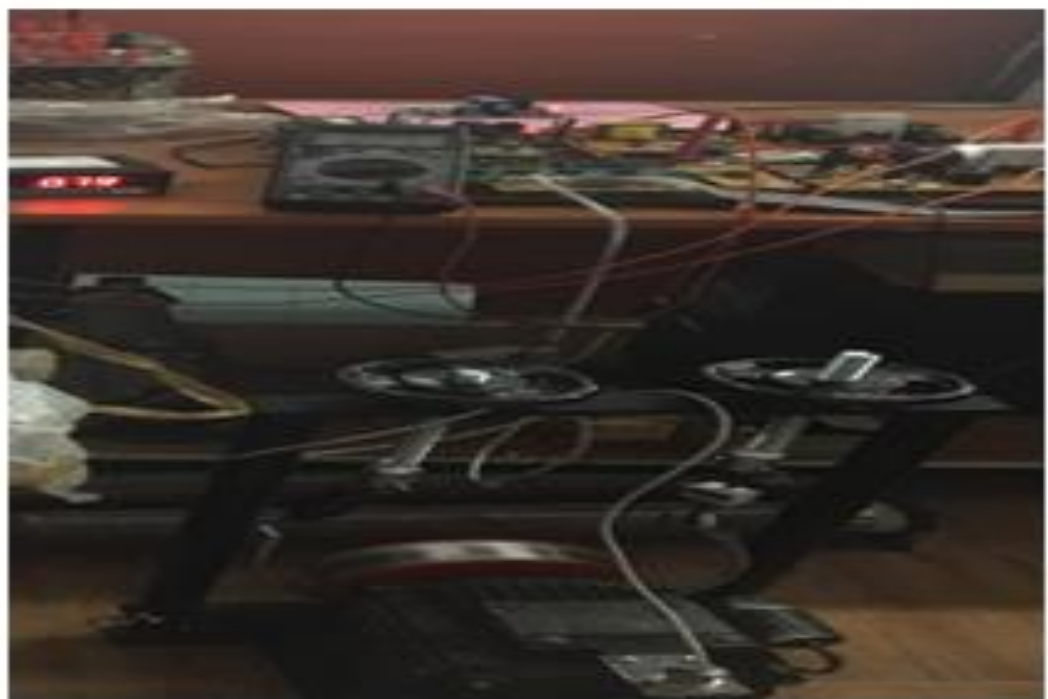

Figure 10. Experimental setup of FPGA controlled capacitor run induction motor

\section{CONCLUSION}

The capacitor run induction motor is derived from $\mathrm{d}-\mathrm{q}$ axis of modeling is a fifth order transfer function. The simple transfer function is derived from the functional points is outlined in the paper. The performance of capacitor run induction motor drive is exhibited using the bacteria foraging optimization technique. The settling time and peak overshoot are taken into considerations for effective dynamic performance. The speed response of optimized PID controllers gives excellent performance under various functional points compared to conventional controllers. The enactment of capacitor run induction motor drive is demonstrated by simulation using matlab and experimental setup using field programmable gate array are obtainable to authenticate the entitlement. The enhancement can be done by sensorless control of online tuning of controller gains. 


\section{ACKNOWLEDGEMENTS}

Authors would like to thank the reviewers for their valuable comments and recommendations to improve the quality of paper.

\section{REFERENCES}

[1] R.Sarayana and S.Thangavel, "Hardware implementation of induction motor using ANN controller under low speed operation," Indonesian Journal of Electrical Engineering and Computer Science (IJEECS), vol. 2, no. 3, pp. 522-529, 2016.

[2] N. Rajasekar and K. Mohanasundaram, "Feedback controller design for variable voltage variable speed induction motor drive via ant colony optimization," Applied Soft Computing, vol. 12, no. 8, pp. 2132-2136, 2012.

[3] K. Sundareswaran and D. Lakshmipriya, "An Evolutionary approach for speed controller design of AC voltage controller fed induction motor drive," Electric Power Components and Systems, vol. 30, no. 10, pp. 1001-1014, 2002.

[4] R. Kameswara rao, P. Srinivas and S. Krantikumar, "Simulation and analysis of electrical water pumping system using solar energy," 2014 International Conference on Smart Electric Grid (ISEG), pp. 1-6, 2015.

[5] Yiwang Wang, Bo Zhang and Hui Pan, "Closed-loop control system of single phase AC FFU motor," Proceedings of the International Conference on Information Engineering and Applications (IEA) 2012, pp. 645-651, 2013.

[6] Ameer Mohammed Jarjees, "Optimal speed control single phase induction motor using fuzzy controller tuning by adaptive tabu seach technique," International Journal of Engineering and Innovative Technology, vol. 5, no 1, pp. 159-166, 2015.

[7] Dirman Hanafi, Mohd Azkar Sidik, Mirza soni and Hidayat, "Time based firing pulse delay control for improving single phase induction motor speed performance using fuzzy logic control," ARPN journal of engineering applied sciences, vol. 11, no. 12, pp. 7515-7521, 2016

[8] Ali. H. Ahmad, Farazdaq R Yasien and Ahmed S Abdullah, " Speed control of single phase induction motor using fuzzy logic controller," American Scientific Research Journal of Engineering, Technology and Sciences, vol. 26, no. 4, pp. 17-29, 2016.

[9] K. Kavya, S. M. Jayashree and Praveena Anjali, "Speed control of single phase induction motor using TRIAC," International journal of emerging research in management technology, vol. 5, no. 5, pp. 352-356, 2016.

[10] Senan M Bashi, I. Aris and S. H. Hamad, "Development of HC single phase induction motor adjustable speed control using M68HC11E-9 microcontroller," Journal of Applied Sciences, vol. 5, no. 2, pp. 249-252, 2005.

[11] A.Shojaei and M Abolhasani far. "Optimal PID control of an induction motor for developing the solar pump using PSO technique," Technical Journal of Engineering and Applied Sciences, vol. 6, no. 2, pp. 64-70, 2016.

[12] Vishal verma, Peeyush pant, Bhim singh, "Simulation of a single phase induction motor with dynamic capacitor for maximum torque operation," in 2008 Joint International Conference on Power System Technology and IEEE Power India Conference, pp. 1-6, 2008.

[13] Bijan Zahedi, Sadegh,Vaez-Zadeh, "Efficiency optimization of single phase induction motors," IEEE Transactions on Power Electronics, vol. 24, no. 4, 1062-1070, 2009.

[14] K. Sundareswaran, N. Rajasekar, V. T. Sreedevi, "Performance comparison of capacitor run induction motor supplied from AC voltage regulator and SPWM chopper," IEEE Trans on Industrial Electronics, vol. 53, no. 3, pp. 990-993, 2006.

[15] K.Sundareswaran, "A improved energy saving scheme for capacitor run induction motor," IEEE Transactions on Industrial Electronics, vol. 48, no. 1, pp. 238-240, 2001.

[16] M. Syed Jamil Asghar, "Smooth speed control of single phase induction motor by integral cycle switching," IEEE transactions on energy conversion, vol. 14, no. 4, pp. 1094-1099, 1999.

[17] Terrance A Lettenmaier, Donald W.Novotony, "Thomas A Lipo. single phase induction motor with an electronically controlled capacitor," IEEE Transactions on Industry Applications, vol. 27, no. 1, pp. 38-43, 1991.

[18] T. A. Lipo, "The analysis of induction motors with voltage control by symmetrically triggered thyristors, "IEEE Transactions on power apparatus and systems, vol. 2, pp.515-526, 1971.

[19] Vladimir Sousa Santos, et al., "Bacteria foraging algorithm application for induction motor field efficiency estimation under unbalanced voltages," Measurement, vol. 46, no. 7, pp. 2232-2237, 2013.

[20] Wenkui Hou and Zhiming Zhang, "A method of test points optimization selection based on improved bacteria foraging algorithm," 2016 Prognostics and System Health Management Conference (PHM-Chengdu), 2017.

[21] N. Murali and V. Balaji, "AC voltage controller fed single phase capacitor run induction motor with different topology," International Journal of Applied Engineering Research, vol. 10, no. 17, pp. 12757-12756, 2015.

[22] N. Murali and V. Balaji, "Pulse width modulated AC voltage controller filter design by optimization technique," International Journal of Scientific Engineering And Technology, vol. 4, no. 10, pp 526-531, 2015.

[23] M. G. Say, The performance and design of alternating current machines : Transformers, three-phase induction motors and synchronous machines, sir isac pitman and sons, London, 1958.

[24] K.Sundareswaran, "A simplified model for speed control of ac voltage controller fed induction motor drives," IETE Journal of Research, vol. 49, no. 4, pp. 247-250, 2003.

[25] K. M. Passino, "Bacterial foraging optimization," Innovations and Developments of Swarm Intelligence Applications, pp. 219-234, 2010.

[26] S. Das, A. Biswas, S. Dasgupta and A. Abraham, "Bacterial foraging optimization algorithm: Theoretical foundations, analysis, and applications," in Foundations of computational intelligence, vol. 3, pp. 23-55, 2009. 


\section{BIOGRAPHIES OF AUTHORS}

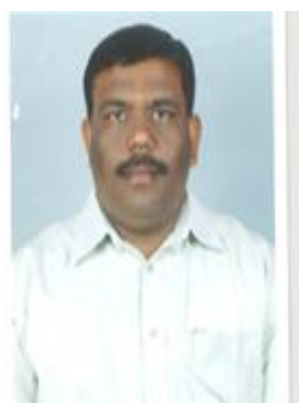

Gobimohan Sivasubramanian is an Indian, Lecturer, Department of Electrical Engineering, Nizwa college of Technology, Oman.He was born in 1975 in Tiruchirappalli, Tamilnadu, India. He received the B.E. degree from Bharathidasan University (1996) and M. E., degree from MIT campus, Anna University in 2000. He has around 24 years of teaching experience. His area of interest includes Renewable energy, Power Electronics, Soft Computing Techniques. He has the ability to look on the better side of life instead of focusing on problems. He has published 4 research papers in international journals and 3 papers in national conferences. He is a Life member Indian society for Technical education.

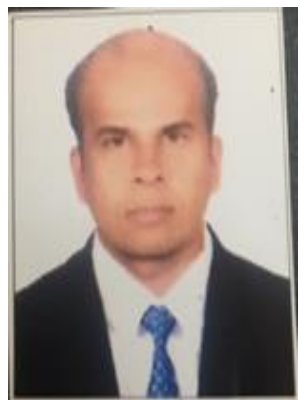

N. Murali has 17 years of teaching experience. Working as a Lecturer in the Department of Electrical Engineering, Nizwa College of Technology, Oman. His current areas of research are Optimization techniques, power electronics and drives, electrical machines design using Ansys, power electronics application in power system, IOT based renewable energy systems and power electronics application in renewable energy systems. He has published 10 research papers in international journals and 10 papers in international and national conferences. He is a Life member of System society of India. 